\title{
Ortaokul Öğretmenlerinin Merhamet ve Zorbalık Kavramlarına İlişkin Algıları1
}

\author{
Secondary School Teachers' Perceptions for the Concepts of Compassion and Bullying
}

\section{Fatih AYDEMİR², Ahmet GÖÇEN³ İbrahim YILDIRIM ${ }^{4}$}

\begin{abstract}
Öz
Merhamet, sıkıntı içerisindeki olana yönelik, vicdanın harekete geçirdiği, acziyeti giderme çabasını içeren fiillerdir. Zorbalık ise güçlü olanın güçsüz olana devamlı ve kasıtlı olarak uyguladığı her türden şiddet eylemidir. Bu araştırmada birbirinin zıddı varsayılan iki kavram ile ilgili öğretmenlerin görüşleri nitel araştırma yöntemlerinden fenomenolojik desen çerçevesinde incelenmiştir. Öğretmenlere "Zorbalık" ve "Merhamet" kavramlarına ilişkin algılarını, bu kavramlarla ilgili gözlemledikleri örnekleri ve bu iki kavram arasındaki ilişki hakkındaki görüşlerini açıklamaları amacıyla yarı yapılandırılmış görüşme formu hazırlanmıştır. Dijital ortamda gerçekleştirilen veri toplama işlemi neticesinde 16 öğretmenin verdiği cevaplar içerik analizi ile incelenmiştir. Buna göre öğretmenlerin zorbalık ve merhamet kavramlarını "bir mıknatısın iki kutbu" şeklinde algıladıkları söylenebilir. Öğretmenler merhameti, acıma hissi ile tüm canlıların iyiliğini isteme ve onlara karşı empatik tutum içerisinde olma kapsamında ortaya çıkan bir duygu şeklinde tanımlarken zorbalığı, kişiye yönelik güç dengesizliği içeren, psikolojik ve fiziksel şiddet davranışına maruz bırakma ve kötü muamelede bulunma türlerini kapsayan bir durum olarak tanımlamaktadır. Bu çalışma ile okullarda görülen zorbalık ve mobbing olaylarına farklı bir bakış açısı sunulmuştur. Bu bakış açısı çerçevesinde okullarda zorbalık ile mücadele çerçevesinde geliştirilecek uygulamalarda merhamet kavramının da bir odak noktası olarak gözden kaçırılmaması önerilmektedir.
\end{abstract}

Anahtar Kelimeler

Merhamet

Zorbalık

Öğretmen algıları Nitel araştırma

\section{Abstract}

Compassion is the deeds that are directed against the troubled one, sparked by the conscience, and involve the effort to resolve the neediness. Bullying, on the other hand, is any act of violence that the strong perpetually and deliberately inflicts on the weak. In this study, the opinions of teachers about these two concepts, which are considered to be opposite of each other, were examined within the framework of phenomenological design, which is one of the qualitative research methods. A semi-structured interview form was prepared for teachers to explain their perceptions of the concepts of "Bullying" and "Compassion", the examples they observed in relation to these concepts and their views on the relationship between these two concepts. The answers given by the teachers upon data collection process carried out in the digital environment were analyzed with content analysis. Accordingly, it can be said that teachers perceive the concepts of bullying and compassion as "two poles of a magnet". Teachers define compassion as a feeling that emerges within the scope of desiring the well-being of all living things and having an empathetic attitude towards them, and define compassion as a situation that includes the imbalance of power, exposure to psychological and physical violence and maltreatment. With this study, a different perspective is presented to bullying and mobbing events in schools. Within the framework of this perspective, it is suggested that the concept of compassion should be given priority as a focal point in practices that will be developed within the framework of combating bullying in schools.

$\begin{array}{ll}\begin{array}{l}\text { Başvuru Tarihi/Received } \\ 21.12 .2020\end{array} & \text { Kabul Tarihi /Accepted } \\ 31.03 .2021\end{array}$

Keywords

Compassion Bullying

Teachers' perceptions Qualitative study

\footnotetext{
${ }^{1}$ Bu çalışmada 2020 yılı öncesine ait veriler kullanıldığı yazarlar tarafından beyan edildiği için etik kurul raporu gerekmemektedir.

2 Sorumlu Yazar, Öğretmen, Millî Eğitim Bakanlığı, Kırkmağara Ortaokulu, Şanlıurfa, TÜRKİYE, (D) https://orcid.org/0000-0002-9863-5842

${ }^{3}$ Dr. Öğr. Üyesi, Harran Üniversitesi, Eğitim Fakültesi, Temel Eğitim Bölümü., Şanlıurfa, TÜRKİYE, (iD https://orcid.org/0000-0002-9376-2084

${ }^{4}$ Dr. Öğr. Üyesi, Gaziantep Üniversitesi, Gaziantep Eğitim Fakültesi, Eğitim Bilimleri Bölümü, Gaziantep, TÜRKIYY, (DD https://orcid.org/0000$\underline{0002-4137-2025}$
}

Dipnot: Çalışma, 6-8 Aralık 2019 tarihinde Almanya'da düzenlenen "2nd International Conference on Future of Teaching \& Education" konferansında "Secondary School Teachers' Perceptions for the Concepts of Compassion and Bullying” başlığılyla sunulan bildirinin genişletilmiş halidir. 


\section{GİRİ̧}

İnsan, sosyal ihtiyaçları olan bir varlıktır. İnsanın hayatını ruhsal olarak sağlıklı bir şekilde sürdürebilmesi için yaşadığı toplumun da sağlıklı ruhsal özellikler göstermesi beklenmektedir. İnsanın hem toplumu etkilediği hem de toplumdan etkilendiği ön kabulünden yola çıkarak toplumdaki olumlu ya da olumsuz insan davranışlarının insanı aynı doğrultuda etkileyeceği söylenebilir. Merhamet kavramı insanlar arası ilişkileri genelde kolaylaştıran, toplumsal ve kişisel sorunları çözmede sosyal ortamın enerjisini pozitif şekilde etkileyen bir kavram olarak karşımıza çıkmaktadır. Bunun yanında da zorbalık kavramı, insanlar arası ilişkileri olumsuz etkileyen, güçlü güçsüz dengesizliğini tetikleyen ve sosyal ortamda bozucu etki gösteren bir kavram olarak belirmektedir.

Zorbalık ile ilgili sistematik olarak nitelendirilen ilk çalışmalar 20. yüzyılın sonlarında Olweus'un öncülüğünde İskandinav ülkelerinde ortaya çımıştır (Yurtal ve Cenkseven, 2016). Küresel anlamda bireysel-özel sebeplerden toplumsal-genel sebeplere kadar birçok faktörden etkilenen zorbalık davranışları ile ilgili çalışmalar Türkiye'de daha sonraları ortaya çıkmıştır.

Zorbalık ile ilgili yapılan çalışmalarda şiddet ve saldırganlık davranışları ile benzer nitelikleri olan zorbalık davranışını bu kavramlardan ayıran bazı özellikler göze çarpmaktadır. Alanyazında zorbalığın diğer şiddet ya da saldırganlık türlerinden farkı olarak ortaya koyulan özellikler şöyle sıralanabilir:

- Kasit içermesi, güç dengesizliği, süreklilik (Olweus, 1999)

- Toplumsal olarak kabul edilebilmesi, psikolojik, fiziksel ya da sosyal nitelik kazanabilmesi (Besag, 1995)

- Korku oluşturma amacı içermesi, planlı olması (Colorosso, 2003)

- Fırsatçılık içermesi, gizli olması (İrfaner, 2009)

$\mathrm{Bu}$ şekilde farklı özellikler ortaya konulmuş olsa da zorbalık kavramının genellikle süreklilik, kasıt ve güç dengesizliği özelliklerini içeren bir olgu olduğu konusunda fikir birliğinden bahsedilebilir (Yıldırım, 2012).

Zorbalık ilgili alanyazında kategorilere ayrılmıştır. Bu kategoriler arasında sözel, fiziksel, duygusal zorbalık, eşyayı izinsiz alma - saklama zorbalığı, ırkçı zorbalık, bozucu zorbalık, cinsel zorbalık (Umutlu, 2010), siber zorbalık (Baker ve Tanrıkulu, 2010; Eroğlu, Aktepe, Akbaba, Işık ve Özkorumak, 2015), dedikodu, dışlama (Yıldırım, 2012) sayılabilir. Bu kategoriler, maruz kalandaki etkileri çerçevesinde genel başlıklar altında toplanırsa fiziksel, psikolojik ve siber olmak üzere üç madde halinde belirtilebilir.

Zorbalık davranışı ile ilgili roller üzerine yapılan araştırmalar sonucunda şu roller ortaya çıkmıştır (Salmivalli, Lagerspetz, Bjorkovist ve ark.,1996, akt.: Yıldırım, 2012):

- Zorba: Zorbalık davranışını gerçekleştirir.

- Zorba Asistanı: Zorbalık sürecine zorbadan daha aktif katılım gösterir.

- Zorba Destekçisi: Zorbalık sürecine pasif destek sağlar (gülme vb.).

- Kurban: Zorbalık sürecinde mağdur olan kişi.

- Kurban Savunucusu: Zorbalık sürecinin bitmesi için aktif çaba gösterir.

- Dışarıda Kalanlar: Zorbalık davranışına tepkisiz kalır.

- Rolü Olmayanlar: Zorbalık süreci ile alakası olmadığını düşünür.

Yukarıda ayrıntılı bir şekilde belirtilen zorbalık sürecindeki roller ise zorba, kurban ve seyirci olmak üzere üç ana başlık altında genellenebilir.

Zorba olarak tanımlanan kişiler çoğunlukla fiziksel olarak güçlü, saldırgan, hemen şiddete başvuran, iletişim becerileri zayıf, başı sıkıştığında kendini kurtarabilen, kendilerine yüksek düzeyde güvenen, dışa dönük, rahat, kolay yalan söyleyebilen, aldırış etmeyen, seçici, inkârcı, pişman olmayan, kötü niyetli, güce eğilimli, teşekkür etmeyen, bencil, esnek olmayan, güvensiz, olgunlaşmamış ve çekicidir. Mağdur olan kişiler ise kendilerine daha az güvenen, endişeli, daha tedbirli, duyarlı, sessiz, kendilerini aktif olarak savunamayan, benlik saygısı düşük, 
kendileri ile ilgili olumsuz fikirleri fazla olan, genelde dışlanmış ve yalnız, çekingen, şiddete başvurmayan, içedönük, endişeli, pasif kişilerdir (İlhan-Alper, 2008; Koç, 2006; Olweus, 1995).

Organization for Economic Cooperation and Development'in [OECD] (2017) 2015 yılında öğrencilerin iyi oluşlarını incelediği raporun zorbalık ile ilgili kısmında Türkiye dâhil bazı ülkelere ilişkin veriler açıklanmıştır. Buna göre Türkiye'deki öğrencilerin \%18,6'sı, Singapur'dakilerin \%25,1'i, İngiltere'dekilerin \%23,9'u, Almanya'dakilerin $\% 15,7^{\prime}$ si, Norveç'tekilerin 17,7'si son bir ayda zorbalık türlerinden birine birkaç kez maruz kaldığı tespit edilmiştir. Türkiye ortalamasının, \%18,7 olan OECD ortalamasına yakın olması Türkiye'nin zorbalık ile ilgili herhangi bir probleminin olmadığı anlamına gelmemektedir. Verilere göre her beş öğrenciden birisi zorbalığa maruz kalmaktadır. Bu sayının artış gösterebileceği ihtimali göz önünde bulundurularak gerekli önlemlerin alınması fayda sağlayacaktır.

Zorbalığa maruz kalan kişiler yaşamlarının ileriki yıllarında bile düşük iyilik hali ve sosyal uyum problemi yaşayabilir ve bu kişilerde psikolojik ve fiziksel rahatsızlıklar görülebilir (Rigby, 2003). Zorbalık ile ilgili söz konusu bu bireysel düzeydeki negatif etkinin yanında sosyal yaşam kurallarının özellikle okullarda bozulması yoluyla toplumsal düzeyde olumsuz etki de gözlenir (Öksüz, Çevik ve Kartal, 2012; Ünalmış ve Şahin, 2012). İnsan sermayesi de zorbalık sonucu artış gösteren kaygı ve depresyondan olumsuz etkilenir (Kapçı, 2004). Merhamet ise zorbalığın tam tersi sayılabilecek etkiler gösterir; öz güveni arttırır, kaygıyı azaltır, depresyonu önleyici etki gösterir, empati, farkındalık ve kendini gerçekleştirme becerilerini arttırır (Sayar ve Manisalıgil, 2014).

Aristoteles'ten Nietzche'ye kadar birçok filozof merhamet üzerine açıklamalarda bulunmuştur. Bu noktada Batı alanyazınındaki tartışmalar ışığında merhametin daha çok duyarlı sevgi anlamı taşıdığı söylenebilir. Türk Dil Kurumu Sözlüğü’nde (TDK, 2018) merhamet kavramı; "bir kimsenin veya başka bir canlının karşılaştı̆̆1 kötü durumdan dolayı duyulan üzüntü ve acıma hissi" olarak tanımlanmıştır. İnsanların toplumsal ruh sağlığını koruyacak bir şekilde yaşaması sosyal hayatın kurallarına uyma ve sağlıklı iletişim kurma ile mümkündür. Merhamet, bir başkasının gereksinimini ya da acısını fark etmek, hissetmek ve bu gereksinimi ya da acıyı ortadan kaldırmaya yönelik eylemler bütünü olarak tanımlanmıştır (Sayar ve Manisalıgil, 2014).

Psikolojik sağlık konusu ile ilgili batı kökenli akımlar, fazla bireysel olması ve bazı sosyal davranışları arka planda değerlendirmesi sebebiyle eleştirilmiştir (Bellah, Madsen, Sullivan, Swidler ve Tipton, 1985). Son zamanlarda, doğu kökenli psikoloji akımlarında kullanılan kavramlardan bilinçli farkındalık, tevazu, öz-anlayış gibi kavramların da batı kökenli psikoloji akımlarında kullanılmaya başlanması, ruh sağlığı ile ilgili olumlu gelişmeler arasında görülebilmektedir. Bu noktada kişinin kendisi ve başkaları için merhametli olması psikolojik sağlığı olumlu yönde etkilediği söylenebilir (Gilbert, 2009). Merhamet mutluluğu, pozitif düşünmeyi ve akıl sağlığını olumlu yönde etkilemekte, pozitif ruh halini artırmakta, stresi azaltmaktadır (Shapira ve Mongrain, 2010).

Merhametin toplum pratiğindeki karşllığı, zorbalık ve şiddetin toplumsal pratikteki karşllı̆ı incelenerek tahmin edilebilir. Zorbalık ve şiddetle ilgili artan medya programları ve sosyal medya haberleri, toplum içinde zorbalık ve şiddet vakalarının arttığına gösterge ya da kanıt olarak sunulabilir. Aile ve Sosyal Politikalar Bakanlığı'nın Kadına Yönelik Aile İçi Şiddet Araştırması (2015) raporundaki verilere göre; ülke genelinde yaşamının herhangi bir döneminde eşinden veya birlikte yaşadığı kişiden fiziksel şiddete maruz kalan kadın nüfus oranı \%35,5'dir. Bu oran, gerçekçi ve kararlı önlemlerin alınması için yeterlidir. Çocukların okul ya da aile ortamında zorbalığa ve şiddete eğilimli çevrede büyüdükleri ve sonraki yaşlarında bir ebeveyn olarak çocuk sahibi oldukları da düşünüldüğünde toplumun bu durumdan olumsuz etkileneceği söylenebilir. Çocukların gelişiminde ektili faktörlerden birisi de öğretmendir. Bir öğrenci günlük zamanının yaklaşık dörtte birini öğretmenleri ile geçirmektedir. Bu da öğretmenlere öğrencileri uzun süreli gözleme imkânı vermektedir. Buradan hareketle eğitim öğretim çalışmalarının kilit aktörü olan öğretmenlerin zorbalık ve merhamet kavramları ile ilgili fikirleri önemli görülerek bu çalışma ortaya konulmuştur.

$\mathrm{Bu}$ çalışma ile merhamet ve zorbalık kavramlarını öğretmenler için ne ifade ettiği ve bu kavramlar arasında bir ilişki olup olmadığı hakkında öğretmenlerin ne düşündükleri araştırılarak konu hakkındaki algılarının belirlenmesi amaçlanmıştır. Bu araştırma ile alanyazında birçok yönü araştırılan zorbalık durumları ile bu 
araştırmalara fazla konu olmayan merhamet olgusu arasında bir ilişkinin varlığı ve durumu ortaya konularak araştırmanın alanyazına katkı sağlayacağı düşünülmüştür. Bunun yanında bu çalışmanın öğretmen görüşlerinden yola çıkarak zorbalık durumlarının çözümüne ilişkin farklı bir bakış açısı getireceği söylenebilir.

\section{YÖNTEM}

$\mathrm{Bu}$ araştırma öğretmenlerin merhamet ve zorbalık kavramlarına yükledikleri anlamları ve bu kavramlar arası ilişkiyi ortaya çıkarmayı hedeflemektedir. Bu nedenle araştırma nitel araştırma yöntemlerinden fenomenolojik (olgubilim) araştırma desenine göre yapılandırılmıştır. Nitel araştırmalar bir problem ya da konunun keşfedilmesi istenildiğinde tercih edilmektedir (Creswell, 2018). Kişilerin bir olguya ait fikirlerinin ve yükledikleri anlamların, deneyimlerin meydana çıkarılmasını içeren araştırmalar fenomenolojik araştırmalar olarak adlandırılmaktadır (Yildırım ve Şimşek, 2008).

\section{Verilerin Toplanması ve Analizi}

Araştırma için öğretmenlerin algılarını incelemeye yönelik taslak sorular literatür taraması sonucunda oluşturulmuş ve bu sorular Eğitim Bilimleri alanında üç uzmanla paylaşılmıştır. Uzmanlardan gelen semantik ve dilbilgisi ile ilgili dönütler doğrultusunda soruların son hali hazırlanmıştır. Ortalama 15 dakikada yanıtlanabilen bu sorular yarı yapılandırılmış görüşme formu olarak Google Formlar aracılı̆̆ıyla 18 öğretmene gönderilmiştir. 16 öğretmenden olumlu cevap alınmış ve veriler toplanmıştır. Online şekilde veri toplanmasının sebebi öğretmenlerin çevresel uyaranların en aza indiği bir ortamda, kişisel bilgi vermeden kendilerini daha iyi ifade edeceklerinin varsayılmasıdır. Öğretmenlerden toplanan yanıtlar, içerik analizi yöntemiyle incelenmiştir. Sonuçlar, katılımcılara verilen takma isimler 1şığında rapor edilmiştir. Takma isimler şu şekilde belirlenmiştir; Ali, Bahri, Ayşe, Büşra, Çetin, Doğan, Çağla, Erdal, Elif, Fatma, Gülseren, Fahri, Hülya, Gürkan, Hüseyin, Irmak'tır. Online formda kişisel detay içeren bölümü doldurmaları katılımcıları için zorunlu tutulmamıştır. Çalışmada e-posta adresi, adı, soyadı, görev yapılan kurum, meslekteki kaçıncı yılı olduğu ve branşı ile ilgili demografik bilgilerden sonra sorulan sorular şu şekildedir:

1. Zorbalık sizin için ne ifade etmektedir?

2. Zorbalık olgusuna ilişkin örnek davranışları okul yaşamınızda gözlemliyor musunuz? Gözlemliyorsanız örnek verir misiniz?

2.a. Yöneticiler ile ilgili örnek

2.b. Öğretmenler ve diğer çalışanlar ile ilgili örnek

2.c. Öğrenciler ile ilgili örnek

3. Merhamet sizin için ne ifade etmektedir?

4. Merhamet olgusuna ilişkin örnek davranışları okul yaşamınızda gözlemliyor musunuz? Gözlemliyorsanız örnek verir misiniz?

4.a. Yöneticiler ile ilgili örnek

4.b. Öğretmen ve diğer çalışanlar ile ilgili örnek

4.c. Öğrenciler ile ilgili örnek

5. Sizce zorbalık ve merhamet arasında ilişki var mıdır? Varsa bu ilişkiyi nasıl açıklarsınız?

Yukarıdaki sorulara alınan cevaplarla öğretmenlerin zorbalık kavramına ilişkin algıları, zorbalık ile ilgili okul ortamındaki çeşitli bağlamlarda (yönetici, öğretmen ve öğrenci) ne tür örneklerle karşılaştıkları, merhamet kavramına ilişkin algıları, merhamet ile ilgili okul ortamındaki çeşitli bağlamlarda (yönetici, öğretmen ve öğrenci) ne tür örneklerle karşılaştıkları ve iki kavram arasındaki ilişkiyi nasıl açıkladıkları incelenerek bu iki kavram arasındaki anlamsal bağ açıklanmaya çalışılmıştır. 
Katılımcılardan elde edilen verilerin içerik analizinde ilk adım tüm verilerin serbest okuması ile gerçekleştirilmiştir. Bu adımdan sonra literatür yeniden gözden geçirilmiştir. Devamında tüm verilerin cümle cümle veya kelime grubu şeklinde kodlanarak okunması ile sürmüştür. Yapılan bu kodlama sonrasında ortaya çıkan kategoriler çerçevesinde tüm veri tekrar incelenerek temalar oluşturulmuştur. Tema oluşturma adımı sonrasında veriler temalara göre yeniden incelenerek kontroller sağlanmıştır.

Verilerin analizi sonucunda zorbalık için 2, merhamet için 1 ve her iki kavram için de ortak olan 6 tema oluşmuştur. Ortak temalar, "Genel Yön” ile kavramın genel olarak neye yönelik olduğu, “Okul İçi Yön” ile kavramın okulda neye yönelik ortaya çıktı̆̆ı, "Gözlem Durumu” ile kavramın okulda gözlenip gözlenmediği, “Öğretmenler İçin Çeşitler" ile kavramın okulda öğretmenler için nasıl gözlendiği, “Öğrenciler İçin Çeşitler” ile kavramın okulda öğrenciler için nasıl gözlendiği, "Yöneticiler İçin Çeşitler" ile kavramın okulda yöneticiler için nasıl gözlendiği şeklinde sıralanmıştır. Buna ek olarak zorbalık kavramı ile ilgili olarak zorbalığın hangi formlarda ortaya çıktığını içeren "Şiddet Formu" ve bir davranışın zorbalık olması için gerekli şartları içeren "Şart" temaları ile merhamet kavramı ile ilgili olarak merhametin aslına ilişkin verileri içeren "Aslına İlişkin" temaları ortaya çıkmıştır.

\section{Katılımcilar}

Örnekleme yöntemi olarak seçkisiz olmayan örnekleme türlerinden benzeşik örnekleme tercih edilmiştir. Benzeşik örneklemede araştırmacılar araştırdığı konuya uygun alt grubu ya da durumu seçmektedir (Büyüköztürk, Çakmak, Akgün, Karadeniz ve Demirel, 2018). Çalışma, merhamet ve zorbalık kavramları ile ilgili öğretmenlerin algıları üzerine kurgulandığı için bu çalışmada katılımcı öğretmenler, okullarda zorbalık ve merhamet olaylarına şahit olma durumlarına göre seçilmiştir. Bu çerçevede araştırmacıların yaşadığı bölge olan Türkiye'nin Güneydoğu Anadolu bölgesindeki bir ilçe merkezinde disiplin sorunlarının en çok olduğu okullarda görev yapan öğretmenler ile iletişime geçilmiştir. Araştırma, araştırmacılar tarafından belirlenen alt grup özelliklerine göre öğretmenlere sanal ortamda gönderilmesiyle başlanmıştır. Öğretmenlerin formu sakin ve zihinsel gürültülerinin az olduğu bir zamanda doldurmaları tavsiye edilmiştir. Bu çerçevede 2018 yılı haziran ayında 18 öğretmen ile iletişime geçilmiştir. Yaşları 24 ile 30 arasında sekizi kadın sekizi erkek olmak üzere 16 öğretmenden detaylı veri sağlanmıştır. Meslekteki görev süresi 1-7 yıl arasında olan ve Türkçe, Fen Bilimleri, Din Kültürü ve Ahlak Bilgisi, İngilizce, Matematik, Görsel Sanatlar ve Psikolojik Danışmanlık alanlarında görev yapan katılımcı öğretmenlerin doldurduğu formlar Microsoft Excel programıla düzenlenmiştir. Sonrasında içerik analizi ile kategoriler ve temalar oluşturulmuştur. Bu analiz sonrasında alanyazın kapsamında değerlendirme yapılmıştır. Devamında araştırmaçların yorumları ile araştırma sonuçlandırılmıştır.

\section{İnandırıcılık}

Nitel araştırmalarda geçerlik ve güvenirlik yerine inandırıcılığın kullanılması önerilmektedir. İnandırıcılık ile ilgili olarak da inanılırlık (credibility), güvenilebilirlik (dependability), onaylanabilirlik (confirmability), aktarılabilirlik (transferability) olmak üzere dört kriter ortaya konmuştur (Guba ve Lincoln, 1982).

Bu kriterlerden inandırıcılık için çalışma; veri toplama, kodlama, tablolaştırma ve raporlaştırma aşamalarında nitel araştırmalar konusunda uzman bir akademisyen tarafından denetlenmiştir. Bunun yanında araştırmacılar konuya ilişkin ön kabullerini belirtmiştir. Güvenilebilirlik ile ilgili araştırmacılar tarafından, ön yargılar nedeniyle uyumsuzluk ve görüşmeler sırasındaki karmaşıklık gibi zayıf yönleri sebebi ile araştırmacılar üçgenleme metodu yerine bulguların kapsamlı analizini içerdiği için (Streubert ve Carpenter, 2011) teori üçgenleme metodu tercih edilmiştir. Böylece elde edilen verilerin alanyazındaki benzer çalışmalar ile olan uyumu ayrıntılı bir biçimde incelenmiştir. Onaylanabilirlik kriteri içinse ham veriler ve analiz edilmiş halleri muhafaza edilmektedir. Çalışma süreci, amacı ve yöntemleri açıkça belirtilmiştir. Aktarılabilirlik ile ilgili olarak katılımcılar ve ortam ayrıntılı bir biçimde açılanmıştır. 


\section{Araştırmacıların Ön Kabulleri}

Konuya ilişkin araştırmacıların görüşleri kısaca ifade edilecek olursa araştırmacılara göre merhamet; insanın zor durumda olan her şeye karşı vicdanı tarafından harekete geçirilen bir eylemdir. İnsanlar, merhamet sayesinde birbirlerine tahammül edebiliyor, güçlüklerle başa çıkabiliyor, iyilikler bu sayede görülüyor ve dünya bunun üzerine ayakta durmaktadır. Zorbalık ise araştırmacılar tarafından merhametin tam zıddı şekilde vicdanın merhameti harekete geçiremeyişinden kaynaklanan fiiller olarak tanımlanmaktadır.

\section{BULGULAR}

Öğretmenlerin zorbalık ve merhamet kavramlarına ilişkin algılarının araştırıldığı bu çalışmada belirlenen tema ve kodlar Şekil 1 ve Şekil 2' de grafik ve kavram haritalarından yararlanılarak sunulmuştur.

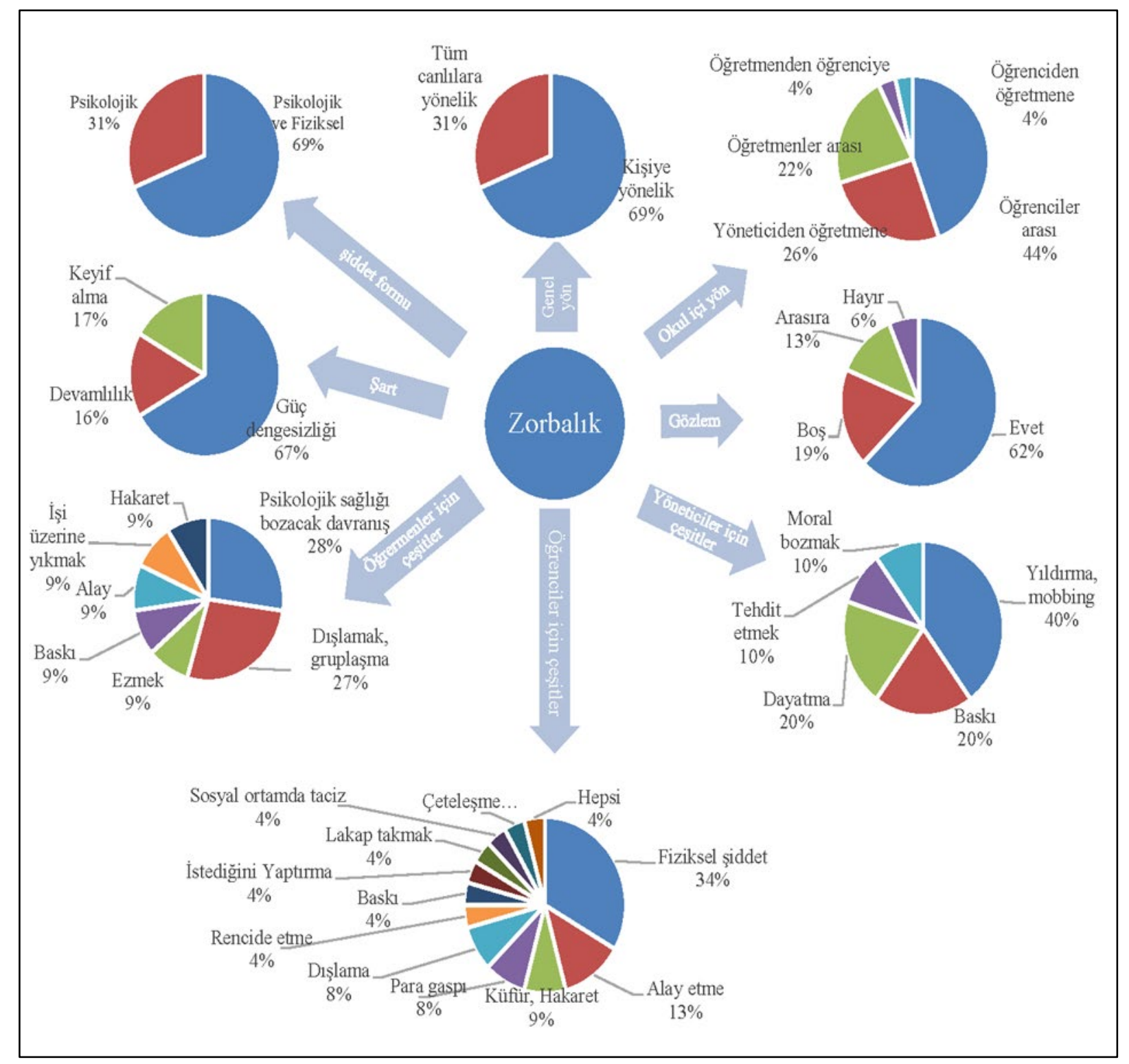

Şekil 1. Zorbalık ile ilgili tema ve kodlara ilişkin kavram haritası

Şekil 1'e göre her bir temada en yüksek puanı alan kategorileri seçerek bir tanım yapılacak olursa araştırmaya katılan öğretmenlerin gözünden zorbalık; kişiye yönelik güç dengesizliği şartıyla psikolojik ve fiziksel şiddetin istenilmeyen davranışa maruz bırakılma ve kötü muamelede bulunulma türlerini içeren bir durumdur. 
Öğretmenlerin yaklaşık üçte biri zorbalığın tüm canlılara yönelik olduğunu dile getirmiş olsa da üçte ikilik kısmı yalnızca insana yönelik olduğunu belirtmiştir. Bu noktada Fahri' nin "Haklı olmayan kişinin, başkası üzerinde yapmış olduğu baskı." şeklinde görüşü örnektir.

Yine üçte ikilik kısım zorbalığın hem psikolojik hem de fiziksel şiddet formlarında kendini gösterebileceğini belirtirken üçte birlik kısmı yalnızca psikolojik formundan bahsetmiştir. Araştırmaya katılan öğretmenlerden hiçbiri fiziksel şiddetten yalnız başına bahsetmemiştir. Gülseren' in bu kapsamdaki fikri “Sadece fiziksel olarak değil insanın psikolojik olarak da sarsılması" şeklindedir.

Katılımcıların bazıları şiddetin zorbalık olması için bazı şartlardan bahsetmiştir. Bu şartlar arasında en çok bahsedileni güç dengesizliği olmuştur. Bunu ise eşit oranlarda keyif alma ve devamlılık takip etmiştir. Bu noktaya Fatma'nın görüşü örnek verilebilir: “Gücün eşit olmadığı durumlarda güçlü olanın güçsüze gösterdiği zarar verici davranışlar".

Zorbalık davranışının gözlenmesine ilişkin öğretmenlerin yaklaşık üçte ikisi gözlemde bulunduğunu belirtmiştir. Katılımcıların zorbalık davranışının nasıl ortaya çıktığına ilişkin algılarının belirtildiği Şekil 1'e göre öğretmenlerin zorbalığı en çok öğrenciler arasında olduğunu düşündükleri görülmektedir. Bunu, birbirine yakın düzeylerde, yöneticiden öğretmene ve öğretmenler arası olduğu belirtilmiştir. Çetin zorbalığın öğrenciler arasında gözlendiğini şu şekilde ifade etmiştir: “Öğrencilerin bir grup hâlinde başka öğrencileri dışlaması.”

Öğretmenlerin yöneticilerde gözlemledikleri zorbalık olarak algıladıkları davranışlar ise en çok bahsedilme sırasına göre yıldırma, baskı, dayatma, tehdit etme ve moral bozma şeklinde sıralamaktadır. Bu noktayı Hülya; "1 dk. derse geç kalan öğretmene psikolojik baskı yapmak, moral bozmak, ek ders kesmekle tehdit etmek." şeklinde ifade etmiştir.

Öğretmenler arası zorbalık davranışlarına ilişkin ise öğretmenler yüksekten düşüğe doğru psikolojik sağlı̆̆ı bozacak davranışlar, dışlamak-gruplaşmak, ezmek, baskı, alay, işi üzerine yıkmak ve hakaret davranışlarından söz etmiştir. Gülseren konuyla ilgili şunları ifade etmiştir: “Bazı öğretmenlerin kendi arkadaşları arasındaki psikolojik baskılar ve gruplaşmaları".

Öğretmenlerin öğrenciler arasındaki zorbalık davranışı olarak algıladıkları davranışlar ise fiziksel şiddet, alay etme, küfür-hakaret, para gaspı, dışlama, rencide etme, baskı, istediğini yaptırma, lakap takma, sosyal ortamda taciz, çeteleşme ve bunların hepsini kapsayan davranışlar olarak sıralanmıştır. Çağla gözlemlerini şu şekilde aktarırken: "birbirlerine karşı çok rahat küfredebiliyorlar ve birbirlerine şiddet uyguluyorlar", Irmak; "Birbirlerini korkutarak eşya ya da paralarını almak, kendilerinin üstün olduğunu düşünen grupların diğer öğrencileri dışlaması" şeklinde aktarmıştır. 


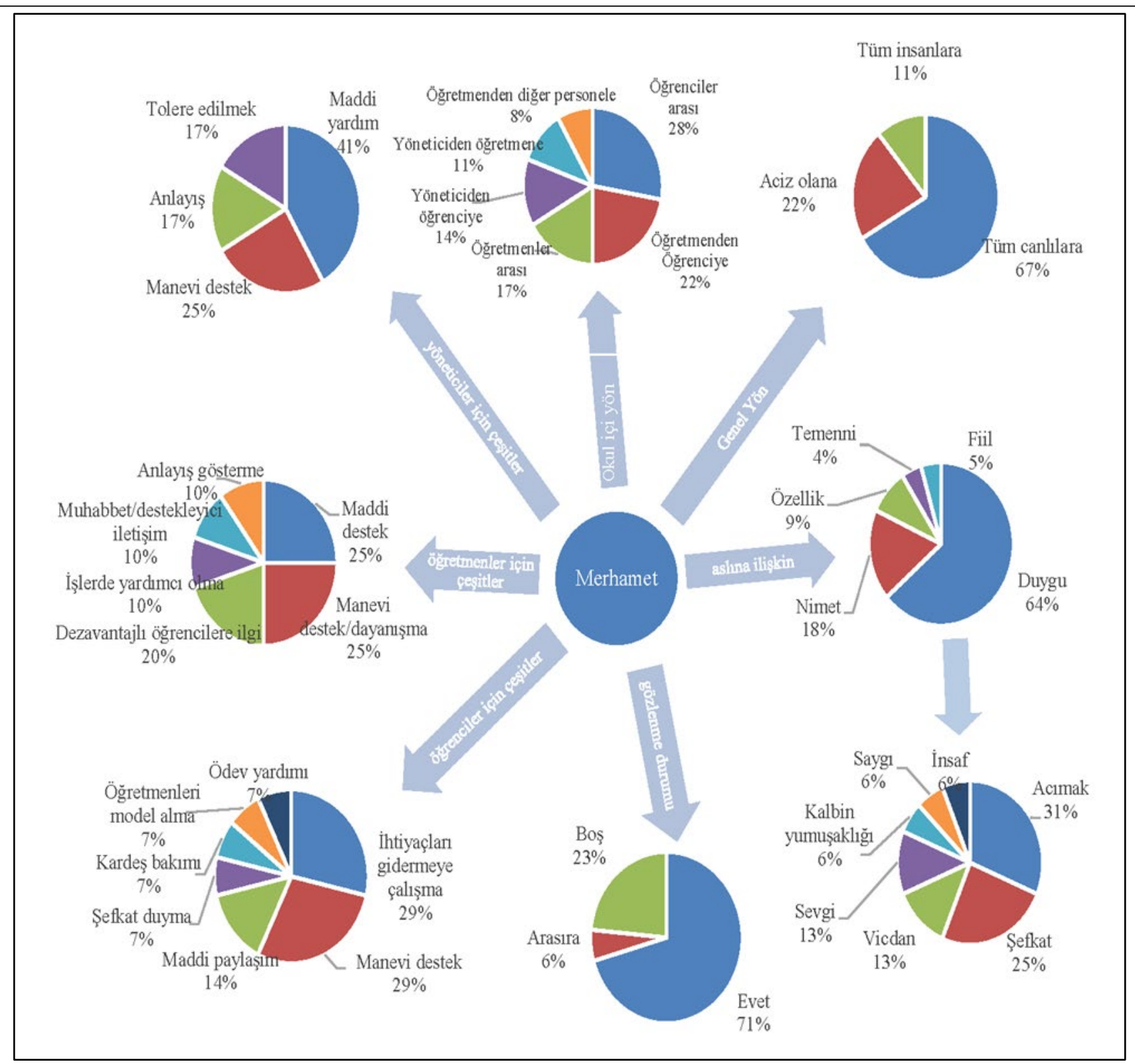

Şekil 2. Merhamet ile ilgili tema ve kodlara ilişkin kavram haritası

Şekil 2'ye göre temalardan alınan en yüksek puanlı kategoriler birleştirilerek bir cümle oluşturulacak olursa katılımcı öğretmenlerin, merhameti şu şekilde tanımladığı söylenebilir: Acıma hissi ile tüm canlıların iyiliğini isteme ve onlara karşı empatik tutum içerisinde olma filleri ile ortaya çıkan bir duygudur.

Öğretmenlerin algılarına göre merhametin yönü tüm canlılara, aciz olana ve tüm insanlara olmak üzere üç şekilde farklılaşmaktadır. Erdal; "İnsanlara acımak, hata yaptıklarında kızmamak ve affetmek", Elif; "Yaratılan her şeye karsı sevgi ve şefkatle bakmak" ve Fatma; “Kötü, çaresiz durumda olan birine kalben acımak" demiştir.

Merhametin aslına ilişkin ise beş farklı görüş ortaya çıkmakla birlikte çoğunluk merhametin bir duygu olduğunda birleşmiştir. Bunu nimet, özellik, temenni ve fiil olabileceği yönündeki görüşler takip etmiştir. Merhameti takip eden duygular ile ilgili ise öğretmenler; acıma, şefkat, vicdan, sevgi, kalbin yumuşaklığı, saygı ve insaf duygularını dile getirmiştir. Bu noktada Ayşe; "şefkat ve acıma duygusudur" diyerek merhametin bir duygu olduğuna vurgu yapmaktadır.

Merhamet ile ilgili örnekleri öğretmenlerin yaklaşık dörtte üçünün çevresinde gözlemlediği tespit edilmiştir. Merhametin hangi yönde gerçekleştiği ile ilgili en çok söz edilen yönün öğrenciler arası olduğu tespit edilmiştir. Bunu öğretmenden öğrenciye, öğretmenler arası, yöneticiden öğrenciye, yöneticiden öğretmene, öğretmenden diğer 
personele olmak üzere farklılaştığı söylenebilir. Ali'nin şu yorumu bu duruma bir örnek sayılabilir; "Gözlemliyorum. Öğrencilerin birbirine yardımcı ve destek olmaları".

Yöneticilerin merhamet örnekleri ile ilgili öğretmenlerin algıları daha çok yöneticilerin öğrencilere maddi yardımı olarak belirtilmiştir. Bunu yöneticilerin tüm paydaşlara manevi desteği, anlayışı ve hataları tolere etmesi takip etmiştir. Bu konuyla ilgili Doğan ve Erdal ortak görüş belirterek "Yetim ve öksüz öğrencilerin belirlenmesi, ilgilenilmesi" yorumunda bulunmuştur.

Öğretmenlerin öğrenciler ile ilgili algıladıkları merhamet davranış çeşidi ise ihtiyaçlarını gidermeye çalışmak ve manevi destek olarak belirtilmiştir. Bunu maddi paylaşım, şefkat duyma, kardeş bakımı, öğretmenleri model alma ve ödev yardımı takip etmiştir. Bu çıkarımla ilgili olarak Büşra ve Gürkan'ın yorumları örnek verilebilir. Büşra; “Öğrencilerin arkadaşlarıyla yiyeceğini, oyununu paylaşması, maddi ve manevi yardımda bulunması”, Gürkan; “Maddi durumu kötü olan öğrenciler için arkadaşları isimleri gizli tutmak kaydıyla yardım kampanyası düzenledi".

Öğretmenlerin kendileri ile ilgili merhamet davranışlarına örnek olarak ise en çok maddi destek ve manevi destek/dayanışmanın olduğu görülmektedir. Sonrasında ise dezavantajlı öğrencilere ilgi, işlerde birbirine yardımcı olma, muhabbet/destekleyici iletişim ve anlayış gösterme merhametin öğretmenler arasındaki yansımaları olarak algılanmaktadır. Bu konuyu Bahri; "Kurumumda genel olarak insanların birbirine karşı merhametli olduğunu şu davranışlarda gözlemliyorum: Hasta olan ya da bir sıkıntısı olan personele diğerlerinin daha anlayışlı davranması, hasta ziyaretinde bulunulması, taziye ziyaretlerine önem verilmesi, yardıma ihtiyacı olan personele maddi destek sağlanması, acil yapması gereken işi olan personelin görev ve sorumluluklarını diğerlerinin yüklenmesi, işi olan personele gerekli izinlerin verilmesi" şeklinde ifade ederken Hüseyin ise "Arkadaş dayanışması" olarak ifade etmektedir.

Tablo 1. Zorbalık ve Merhamet Kavramları Arasındaki İlişki

\begin{tabular}{ccc}
\hline Tema & Kategori & Sayı \\
\hline & Doğru Orantı & 0 \\
Cevap & Ters Orantı & 15 \\
& İlişki yok & 1 \\
\hline
\end{tabular}

Araştırmaya katılan öğretmenlerin hemen hemen hepsi zorbalık ve merhamet arasındaki ilişkiyi ters yönlü olduğunu farklı mecazlar kullanılarak tanımlamaktadır. Nitekim Fahri şöyle demiştir: “Merhamet ve zorbalığın aynı kişide bulunacağına inanmıyorum. Ateş ve su gibi. Ya yanacaksın ya da söneceksin”. Bir diğer deyişle merhamet ve zorbalığın öğretmenler tarafından birbirinin zıddı kavramlar olarak algılandığı söylenebilir.

\section{TARTIŞMA VE SONUÇ}

$\mathrm{Bu}$ araştırma öğretmenlerin zorbalık ve merhamet kavramlarını nasıl algıladıklarını ortaya çıkarmak ve iki kavram arası algılanan ilişkiyi incelemek amacıyla yapılmıştır. Bunun için 16 öğretmenden dijital ortamda, görüşme soruları aracılığıyla veri toplanmıştır. Fenomenolojik nitel araştırma deseninde gerçekleştirilen içerik analizi sonucunda elde edilen veriler doğrultusunda öğretmenlerin zorbalık ve merhamet ile ilgili çok boyutlu zihinsel şemalara sahip olduğu söylenebilir.

Öğretmenlerin algılarına göre zorbalık ile ilgili 8 tema, merhamet ile ilgili 7 tema ve ikisinin ilişkisine ait 2 tema ortaya çıkmıştır. Zorbalık ile ilgili temalar “Genel Yön, Okul içi Yön, Gözlem Durumu, Şiddet Formu, Şart, Öğretmenler için Örnekler, Öğrenciler için Örnekler, Yöneticiler için Örnekler" şeklinde ortaya çıkmışken merhamet ile ilgili temalar da “Genel Yön, Okul içi Yön, Aslına İlişkin, Gözlem Durumu, Öğretmenler için Örnekler, Öğrenciler için Örnekler, Yöneticiler için Örnekler" şeklinde ortaya çıkmıştır.

Öğretmenler, genel olarak merhametin tüm canlılara yönelik olduğunu söylerken zorbalığın yalnızca insanlara yönelik olduğunu belirtmiştir. Nitekim zorbalık kavramı alanyazında da daha çok insanlara yönelik kullanılmaktayken (Yıldırım, 2008), merhamet insan ya da tüm canlılar için (Koç, 2015) kullanılmaktadır. 
Öğretmenlerin algılarına göre okulda merhamete ilişkin davranışlar zorbalığa ilişkin davranışlardan daha fazla olmaktadır. Yine öğretmenlerin neredeyse tamamının kanaatine göre zorbalık ve merhamet kavramları birbiriyle ters orantılı olarak ortaya çıkmaktadır. Zorbalık okul içinde öğretmenlerin gözünde en çok öğrenciler arasında meydana gelmektedir. Bunu yöneticiden öğretmene yönelik davranışlar takip etmektedir. Öğrenciler arası zorbalık davranışlarına daha sık rastlanması öğrenci sayısının öğretmen ve yönetici sayısından kat kat fazla olması ve öğrenci yaş gruplarındaki bedensel/kişisel gelişim durumları sebebiyle açıklanabilir. Öğretmenden öğrenciye ve öğrenciden öğretmene yönelik zorbalık davranışları ise en az orana sahiptir. Merhamet ise okul içinde en çok öğrenciler arasında gözlenmekte ve bunu öğretmenden öğrenciye yönelik davranışlar takip etmektedir. Yöneticilerden öğretmene yönelik merhamet davranışları algılanan en az düzeyde yer almaktadır. Öğretmenlerin zihinsel şemalarına göre okuldaki zorbalık olayları en az öğretmenden öğrenciye ve öğrenciden öğretmene olarak ortaya çıkarken merhamet davranışları en az öğretmenden diğer personele ve yöneticiden öğretmene olarak ortaya çıkmaktadır. Bu noktada yöneticiler zorbalık ile ilgili yüksek bir orana sahipken merhamet ile ilgili düşük bir orana sahiptir. Esemen (2015)'in yaptığı çalışmaya göre de öğretmenler kendilerine yönelik mobbing davranışlarının en çok yöneticilerden geldiğini belirtmiştir.

Öğretmenlerin zihinsel şemalarına göre bir davranışın zorbalık sayılması için bazı şartları taşıması gerekmektedir. Bunlar ağırlıklarına göre güç dengesizliği, keyif alma ve devamlılıktır. Yıldırım (2012) da bir davranışın zorbalık sayılabilmesi için güç dengesizliği, kasıt ve süreklilik şartlarını sağlaması gerektiğini belirtmektedir. Bu noktada öğretmenlerin keyif alma şartı, kasıt olarak düşünülürse alanyazınla bir mutabakat sağlandığı söylenebilir. Yine öğretmenlerin çoğunluğuna göre zorbalık psikolojik ve fiziksel şiddeti içerirken bir kısmına göre sadece fiziksel şiddeti içermektedir. Yapılan araştırmalarda da zorbalık psikolojik ve fiziksel şiddeti ayrı ayrı ya da birlikte içeren fiiller olarak kategorilendirilmektedir. Nitekim İlhan-Alper (2008)'e göre zorbalık, karşıdakine fiziksel, sosyal, zihinsel ya da psikolojik olarak zarar verme amacıyla yapılan kasıtlı söz ve fiillerdir. Bu noktada da öğretmenlerin zihinsel şemaları diğer çalışmalar ile örtüşmektedir.

Öğretmenler, merhametin kendisinin aslına ilişkin olarak daha çok bir duygu olduğunu algılamaktadır. Bu duyguyu ise en çok acıma ve şefkat olarak isimlendirmektedirler. Merhamet en az düzeyde ise bir fiil olarak algılanmaktadır. Merhamet, alanyazında ihtiyaç sahibinin ihtiyacının acıma duygusu ile karşılanması şeklindeki bir fiil olarak tanımlanmaktadır (Gazali, 1975). Öğretmenlerin, merhameti neden bir fiil değil yalnızca bir duygu olarak algıladıkları açıklanmaya muhtaç bir konudur. Bu nokta öğretmenlerin güncel kavramsallaştırması olarak ele alınabilir. Örneğin: yaşı ileri kişilerin "merhamet etmek" şeklinde ifade ettiği olgu, yaşı daha genç kişilerce "merhametli olmak" şeklinde ifade edilebilmektedir. Birinci ifadede merhamet, "edilen", "eylenen" bir fiildir. İkinci ifade ise "olmak" fiilini nitelemektedir. Dolayısıyla fiil olarak ifade edilmemektedir. Bu durum meslekteki görev süresi 1-7 yıl olan katılımcıların ifadelerinde duygu olarak yerini almaktadır.

Öğretmenlerin, öğrencilerde en çok gözlemledikleri zorbalık davranışı, fiziksel şiddet olarak ortaya çıkmıştır. Bu durum öğretmenlerin, zorbalığın hangi formlarda ortaya çıktığını ifade ederken fiziksel ve psikolojik şiddetten ayrı olarak fiziksel şiddeti de belirtmeleri ile açıklanabilir. Bunun yanında sözü edilen zorbalık davranışları ise alanyazında karşılığını bulmaktadır. Şöyle ki Kepenekçi ve Çınkır’ın (2003) yaptı̆̆ çalışmada da fiziksel şiddet en çok görülen tür olarak belirtilmiştir. Öğretmenlerin yöneticilerde en çok gördükleri zorbalık davranışı yıldırma ve mobbing olmakla birlikte bunu baskı takip etmiştir. Öğretmenler arası en çok gözlenen zorbalık davranışları ise psikolojik sağlığı bozacak davranışlar ve dışlamak olarak ortaya çıkmıştır. Örgütlerdeki çalışanlar arasında gerek yatay gerek dikey olarak gerçekleştirilen bu davranışlar ve öğretmenler tarafından sözü edilen diğer zorbalık davranışları alanyazında mobbing olarak tanımlanmaktadır. Örneğin; Namie (2003), çalışmasında mobbing kavramı için iş yeri zorbalığı kavramını kullanmıştır. Bu noktada öğretmenlerin algıları ile alanyazın örtüşmektedir.

Merhamet ise öğretmenler tarafından öğrencilerde en çok birbirinin ihtiyacını giderme ve manevi destek olarak gözlemlenmiştir. Yöneticilerde gözlemlenen merhamet davranışları ise en çok öğrencilere maddi yardım sağlama ve manevi destek olarak ortaya çıkmıştır. Öğretmenlere göre, merhamet öğretmenler arasında en çok maddi ve manevi destek olarak kendini göstermiştir. Merhametin, öğretmenler tarafından, yönetici, öğretmen ve öğrenciler 
için gerek maddi gerekse manevi ihtiyaçların giderilmesinin ortak olarak algılanması ilgi çekicidir. Zorbalık ile ilgili yönetici, öğretmen ve öğrenciler için farklı farklı davranışlardan söz eden öğretmenlerin söz konusu merhamet olduğunda ortak bir noktada buluşmaları incelenmesi gereken bir nokta olarak karşımıza çıkmaktadır.

\section{ÖNERİLER}

Öğretmen algılarına göre zorbalık ve merhamet kavramları ateş ve su gibi birbirinin zıddı kavramlardır. Buna göre okullardaki zorbalık ve mobbing durumlarının azaltılması için merhameti harekete geçirecek çalışmalar uygulanabilir. Söz konusu bu çalışmaların zorbalık ve mobbing davranışlarının azalmasında olumlu etki göstereceği düşünülmektedir. Bu çalışmaların bir program dâhilinde ve öğretmenler ile öğrencilerin gönüllü katılımlarıyla olmasının da etkiyi arttıracağı söylenebilir. Öğretmenlerin öğrencilerdeki merhameti geliştirecek sınıf yönetimi stratejileri geliştirmeleri, zorbalığın üzerinde negatif etki gösterebilir. Zorbalığın farklı durum ve öznelerde ayrı ayrı davranışlar şeklinde gözlemlenirken merhametin neredeyse aynı şekilde algılanması incelenmesi gereken diğer bir konudur. Araştırması önerilen bir diğer alan ise merhamet ve zorbalık kavramları arasındaki nedenselliğin sorgulanması çerçevesinde yapılabilir. 


\section{KAYNAKÇA}

Baker, Ö. E., \& Tanrıkulu, İ. (2010). Psychological consequences of cyber bullying experiences among Turkish secondary school children. Procedia-Social and Behavioral Sciences, 2(2), 2771-2776.

Bellah, R. N., Madsen, R., Sullivan, W. M., Swidler, A., \& Tipton, S. M. (1985). Habits of the heart: Individualism and commitment in American life. Berkeley: University of California Press.

Besag, V. (1995). Bullies and victims in schools. Philadelphia: Open University Press.

Büyüköztürk, Ş., Çakmak, E. K., Akgün, Ö. E., Karadeniz, Ş. \& Demirel, F. (2018). Bilimsel araştırma yöntemleri. Ankara: Pegem Akademi Yayıncılık.

Colorosso, B. (2003). The bully, the bullied, and the bystander. New York: Harper Resource.

Creswell, J. W. (2018). Nitel araştırma yöntemleri: Beş yaklaşıma göre nitel araştırma ve araştırma deseni. (M. Bütün ve S. B. Demir, çev.). Ankara: Siyasal Kitabevi.

Eroğlu, Y., Aktepe, E., Akbaba, S., Işık, A., \& Özkorumak, E. (2015). Siber zorbalık ve mağduriyetin yaygınlığının ve risk faktörlerinin incelenmesi. Eğitim ve Bilim, 40(177), 93-107.

Esemen, D. (2015) Anadolu liselerinde çalışan öğretmenlerin mobbing uygulamalart ile ilgili algıları: Özel ve devlet okullarının karşılaştırılması. (Yayınlanmamış yüksek lisans tezi). Akdeniz Üniversitesi, Eğitim Bilimleri Enstitüsü, Antalya.

Gazali. (1975) Kimya-yı Saadet. (A. F Meyan, çev.). İstanbul: Bedir Yayınevi.

Gilbert, P. (2009). Introducing compassion-focused therapy. Advances in psychiatric treatment, 15(3), 199-208.

Guba, E. G., \& Lincoln, Y. S. (1982). Epistemological and methodological bases of naturalistic inquiry. Educational Communication and Technology Journal, 30(4), 233-252.

İlhan-Alper, S. (2008). İlköğretimde zorbalık. (Yayınlanmamış yüksek lisans tezi). Uludağ Üniversitesi, Sosyal Bilimler Enstitüsü, Bursa.

İrfaner, S. (2009). Ö̆grenciler arasında gerçekleşen zorbalı eylemleri ve zorbalık konusunda öğrencilerin, öğretmenlerin ve okul yöneticilerinin tutum ve görüşleri. (Yayımlanmamış doktora tezi). Hacettepe Üniversitesi, Sosyal Bilimler Enstitüsü, Ankara.

Kapçı, E. G. (2004). İlköğretim öğrencilerinin zorbalığa maruz kalma türünün ve sıklığının depresyon, kaygı ve benlik saygısıyla ilişkisi. Ankara Üniversitesi Ĕ̆itim Bilimleri Fakültesi Dergisi, 37(1), 1-13.

Kepenekçi, Y. K. \& Çınkır, Ş. (2003). Öğrenciler arası zorbalık. Kuram ve Uygulamada Eğitim Yönetimi, 34(34), 236-253

Koç, Z. (2006). Lise öğrencilerinin zorbalık düzeylerinin yordanması. (Yayınlanmamış doktora tezi). Gazi Üniversitesi, Eğitim Bilimleri Enstitüsü Ankara.

Koç, Z. H. (2015). Vicdanın ahlâkî ve teolojik temelleri. (Yayınlanmamış yüksek lisans tezi). Ankara Üniversitesi, Sosyal Bilimler Enstitüsü, Ankara.

Namie, G. (2003). Workplace bullying: Escalated incivilitiy. USA: Ivey Business Juornal.

Olweus, D. (1995). Bullying at school. Oxford: Blackwell Company.

Olweus, D. (1999). Bullying prevention program. Boulder, CO: Center for the Study and Prevention of Violence, Institute of Behavioral Science, University of Colorado at Boulder.

Organization for Economic Cooperation and Development (OECD). (2017). PISA 2015 results (volume III): Students' well-being. (05.05.2018 tarihinde https://read.oecd-ilibrary.org/education/pisa-2015-results-volumeiii_9789264273856-en\#page1 adresinden alınmıştır.)

Öksüz, Y., Çevik, C. \& Kartal, A. (2012). İlköğretim 4. ve 5. sınıf öğrencileri arasındaki zorbalık olaylarının çeşitli değişkenlere göre incelenmesi (Rize ili örneği). Turkish Studies - International Periodical for the Languages, Literature and History of Turkish or Turkic, 7(3), 1911-1934. http://dx.doi.org/10.7827/TurkishStudies.3701

Rigby, K. (2003). Consequences of bullying in schools. The Canadian Journal of Psychiatry, 48(9), 583-590. 
Sayar, K. \& Manisalıgil, A. (2014). Merhamet devrimi: Merhamet dünyamızı nasıl aydınlatabilir? İstanbul: Timaş Yayınları

Shapira, L. B., \& Mongrain, M. (2010). The benefits of self-compassion and optimism exercises for individuals vulnerable to depression. The Journal of Positive Psychology, 5(5), 377-389.

Streubert, H. J., \& Carpenter, D. R. (2011). Qualitative research in nursing. (5th ed.). Philadelphia: Lippincott Williams ve Wilkins.

T.C. Aile ve Sosyal Politikalar Bakanlığı, Kadın Statüsü Genel Müdürlüğü. (2015). Türkiye'de Kadına Yönelik Aile İçi Şiddet Araştırması. (05.05.2018 tarihinde http://kadininstatusu.aile.gov.tr/data/542950d5369dc32358ee2bba/ Ana\%20Rapor.pdf adresinden alınmıştır.)

Türk Dil Kurumu (TDK). (2018). Güncel Türkçe Sözlük. http://www.tdk.gov.tr/index.php?option=com gts\&arama =gts\&guid=TDK.GTS.5bf169934241b0.30410158 Erişim tarihi: 18.11.2018

Umutlu, Ç. (2010). Çocuk dostu okul projesi kapsammda olan ve olmayan ilköğretim okulu öğrencilerinin özgüvenleri ile zorbalık eğilimlerinin incelenmesi. (Yayınlanmamış yüksek lisans tezi). Yeditepe Üniversitesi, Sosyal Bilimler Enstitüsü, İstanbul.

Ünalmış, U. M. ve Şahin, R. (2012). Şiddete yönelik tutum ve okul zorbalı̆̆ı. Cumhuriyet Uluslararası Eğitim Dergisi, $1(1), 63-71$.

Yıldırım, A. \& Şimşek, H. (2008). Sosyal bilimlerde nitel araştırma yöntemleri (7. Baskı). Ankara: Seçkin Yayıncılık.

Yıldırım, R. (2012). Akran zorbalığı. Manisa Celal Bayar Üniversitesi Sosyal Bilimler Dergisi, 10(2), 39-51.

Yıldırım, T. (2008). İlköğretim okullarında öğretmen-yönetici ilişkilerinde yıldırma ve etkileri. (Yayınlanmamış yüksek lisans tezi). Yeditepe Üniversitesi, Sosyal Bilimler Enstitüsü, İstanbul.

Yurtal, F. \& Cenkseven, F. (2007). İlköğretim okullarında zorbalığın yaygınlığı ve doğası. Türk Psikolojik Danışma ve Rehberlik Dergisi, 3(28), 1-13. 


\section{Extended Abstract}

\section{Purpose and Significance}

The purpose of this study, in which the concepts of compassion and bullying are questioned with teachers, is to determine the perceptions of teachers regarding these two concepts. It is thought that this research will contribute to the literature by revealing the existence and status of a relationship between bullying and compassion, which is not much researched. In addition, it can be said that the study will bring a different perspective in the solution of bullying situations based on the opinions of the teachers,

\section{Methodology}

This research aims to reveal the meanings attributed to the concepts of compassion and bullying by teachers. For this reason, the research was designed according to phenomenological research, one of the qualitative research methods. Qualitative research is preferred when a problem or subject is desired to be discovered (Creswell, 2018). Research that involves revealing the ideas and implications of a person on phenomena or facts is called phenomenological research (Yıldırım \& Şimşek, 2008). For the research, questions about teachers' perceptions on both concepts were prepared by taking the opinions of three experts in the field of educational sciences. The questions in semi structured form were sent to the teachers in Turkey's Southeastern region with the help of Google Forms and answered in detail.

\section{Trustworthiness}

In qualitative research it is recommended to use trustworthiness instead of validity and reliability. In terms of trustworthiness, four criteria have been put forward as credibility, dependability, confirmability, and transferability (Guba \& Lincoln, 1982).

For credibility, it was controlled and checked by an academician who was qualified in qualitative research in the stages of data collection, coding, tabulation, and reporting. In addition, the researcher stated his preliminary assumptions on the subject. The theory triangulation method was preferred by the researcher about dependability. Thus, the consistency of the data obtained in similar studies in the literature was examined in detail. For the confirmability, the raw data and analyzed forms were retained. The study process, purpose and methods were clearly stated. Regarding transferability, the participants and the environment were explained in detailed way.

\section{Results}

Bullying in the eyes of the teachers in the research is a condition that includes psychological and physical violence, undesirable behavior, and abuse, provided that there is an imbalance of power to the individual. Approximately two-thirds of teachers stated that bullying can manifest itself in both psychological and physical forms of violence, while one-third stated only psychological forms. None of the teachers who participated in the study mentioned physical violence alone.

Some of the participants mentioned some conditions for violence to be named as bullying. The most mentioned condition among them was the imbalance of power. This was followed by enjoyment and continuity. About twothirds of teachers reported that they observed bullying behavior in their close environment. Teachers also reported bullying by the school management. The behaviors perceived as bullying by the teachers from school administrators were stated to be similar to intimidation, oppression, imposing, threatening and demoralization. Regarding bullying behaviors among teachers, teachers talked about bullying behaviors like exclusion-grouping, oppressing, ridiculing, and insulting. The behaviors perceived by the teachers as bullying behavior among the students were listed as physical violence, ridiculing, swearing-insulting, money taking, exclusion, offending, oppression, doing what they want, nicknaming, harassment in the social environment.

If a sentence is formed by combining the highest-rated categories from the themes of compassion, it can be said that the participants define compassion as follows: "Compassion is a feeling that emerges with the feeling of pity and the act of asking for the good of all living things and being empathic towards them". According to teachers' 
perceptions, compassion differs in three ways, for all living beings, the powerless and all human beings. Five different views on the concept of compassion emerged, but the majority agreed upon that compassion is a feeling. This was followed by views that it could be blessing, trait, wish and act. In the interviews, compassion was found to be observed mainly among students. It can be said that it differs from teacher to student, among teachers, from manager to student, from manager to teacher and from teacher to other staff. Teachers 'perceptions on examples of compassion by school managers were mostly expressed as financial aid to the students. This was followed by managers' moral support, understanding and tolerance for all stakeholders. The kind of compassion behavior perceived by the teachers about the students was stated as trying to meet their needs and providing spiritual support. This was followed by financial assistance, showing affection, care, being a model as teacher and homework help. As examples of teachers' compassion behaviors among themselves, it is seen that financial support and moral support / solidarity are the most common. Afterwards, attention to disadvantaged students, helping each other at work, showing affection / supporting communication and understanding are perceived as reflections of compassion among teachers.

Almost all of the teachers who participated in the study described the relationship between bullying and compassion as opposite terms.

\section{Discussion and Conclusion}

According to the results of the study, the majority of the teachers said that compassion was directed towards all living things (Koç, 2015), while bullying was only directed at people (Yıldırım, 2008).

Bullying in the eyes of the teachers in the research is a condition that includes psychological and physical violence, undesirable behavior, and abuse, provided that there is an imbalance of power to the individual. According to the teachers' mental schemes, a behavior must meet certain conditions in order to be considered as bullying. These are power imbalance, pleasure, and continuity according to their weight. Yildırım (2012) states that in order for a behavior to be considered bullying, it must meet the conditions of power imbalance, intent and continuity.

According to teachers' perceptions, behaviors related to compassion in school are more than bullying behaviors. Teachers in this study think that compassion as more of a feeling. They call this feeling the most as pity and affection. At a minimum, it is perceived as an act. Compassion is described in the literature as the meeting the needs of a person in need with a feeling of pity (Gazali, 1975).

Teachers were found to observe mostly physical violence in bullying cases among students. As for compassion, teachers were mainly faced with helping the needy and moral support among the students. According to the perceptions of the teacher, the concepts of bullying and compassion are opposite to each other like the two poles of the magnet.

About the study implications, it can be said that studies can be done to reduce compulsion and bullying in schools by placing specific programs that considers the opinions of teachers in the study. It can be thought that these studies will have a positive effect on decreasing bullying and mobbing behaviors. It can be said school wide programs and studies with the voluntary participation of teachers and students will increase the positive effect.

\section{Araştırmanın Etik Taahhüt Metni}

Yapılan bu çalışmada bilimsel, etik ve alıntı kurallarına uyulduğu; toplanan veriler üzerinde herhangi bir tahrifatın yapılmadığı, karşılaşılacak tüm etik ihlallerde "Manisa Celal Bayar Üniversitesi Eğitim Fakültesi Dergisi ve Editörünün" hiçbir sorumluluğunun olmadığı, tüm sorumluluğun Sorumlu Yazara ait olduğu ve bu çalışmanın herhangi başka bir akademik yayın ortamına değerlendirme için gönderilmemiş olduğu sorumlu yazar tarafından taahhüt edilmiştir. 